
Balkan Araştırma Enstitüsü Dergisi / Journal of Balkan Research Institute
Cilt/Volume 7, Sayı/Number 2, Aralık/December 2018, ss. 341-366.

Geliş Tarihi-Received Date: 11.10.2018

Kabul Tarihi-Accepted Date: 07.11.2018

DOI: $10.30903 /$ Balkan.504201

ARAŞTIRMA MAKALESI - RESEARCH ARTICLE

\title{
ANKARA ELÇISİ RAUF FİCO’NUN GÜNLÜKLERİ IŞIĞINDA KRALLIK İLANI ÖNCESİ TÜRKIYY-ARNAVUTLUK İLIŞKILERINE ATATÜRK’ÜN YAKLAŞIMI
}

\section{Halil ÖZCAN*}

\begin{abstract}
öz
Arnavutluk Ankara Orta Elçisi Rauf Fico'nun günlükleri, bize bugüne kadar literatürde rastlanmayan birçok faydalı bilgi vermektedir. Çalışmanın amacı, Atatürk'ün, Arnavutluk-Türkiye ve Arnavutluk-İtalya ilişkileri hakkındaki görüşlerini ve Ankara'daki Arnavutluk elçisine verdiği Arnavutluk'un İtalya'nın bağımlılığına nasıl girmeyeceği konusundaki önerilerini ortaya koymayı amaçlamaktadır. $\mathrm{Bu}$ araştırma Ankara'nın Arnavutluk Orta Elçisi Fico'nun günlükleri üzerine kurulmuştur. Çalışma, iki bağımsız ülke arasındaki ilişkileri incelemekten ziyade, Arnavutluk'un Türkiye ile ilişkilerinde İtalya'nın etkisi ile sinırlandırılmıştır.

Resmî eğitimini Osmanlı İmparatorluğunda tamamlayan ve kaymakamlık gibi önemli mülkî (bürokratik) görevlerde bulunan, Arnavutluk'un bağımsızlığını kazanmasından sonra Arnavutluk Hükümeti'nde önemli bir diplomat olarak görev alan Fico'nun günlükleri, 1925-1928 yılları arasında Cumhuriyet rejiminin devam ettiği Arnavutluk'un Türkiye ile ve aynı zamanda İtalya ile olan ilişkileri hakkında oldukça fazla bilgi vermektedir.

Fico'nun günlükleri, Türkiye ve Arnavutluk'un yakın ilişkileri hakkında ve 1928 yılında Arnavutluk Kralı Ahmet Zogu'nun ilan ettiği Cumhuriyet rejimini yıkmasına kadar, Mustafa Kemal Atatürk'ün bu ilişkiye verdiği önem hakkında da bilgiler vermektedir. Fico'nun günlükleri, İstanbul'daki Ortodoks Arnavutların sorunları, Kosova'daki Arnavutların durumu, Çamerya Arnavutlarının mübadelesi, Türkiye'nin reformları, Atatürk'e İzmir suikastı girişimi ve Nutuk'un yazımı ana temalarıyla ilgili zengin bilgiler içermektedir. Unutulmamalıdır ki, bu çalışmanın
\end{abstract}

\footnotetext{
* Dr. Öğr. Üyesi, Başkent Üniversitesi, Atatürk İlkeleri Uygulama ve Araştırma Merkezi (Atamer), Ankara, ORCID: orcid.org/0000-0002-6294-2576, E-mektup: hozcan@baskent.edu.tr
} 


\title{
HALİL ÖZCAN
}

kapsamı, Ankara'da bulunan Arnavut diplomat Fico aracılı̆̆ı ile İtalya'nın bağımlılığından kurtulması için Arnavutluk Hükümetine Atatürk'ün yaptığı öneriler ve İtalya'nın Arnavutluk, Türkiye üzerindeki tutumu ile ilgili öngörülerle sınırlandırılmıştır.

Anahtar Kelimeler: Türkiye, Arnavutluk, Rauf Fico, Günlük, Bağımlılık.

\section{THE APPROACH OF ATATÜRK TO RELATIONS BETWEEN TURKEY AND ALBANIA BEFORE THE PROCLAMATION OF MONARCHY, IN THE LIGHT OF THE DIARIES OF RAUF FICO, THE MINISTER PLENIPOTENTIARY OF ANKARA}

\begin{abstract}
The diaries of Rauf Fico, Albanian Minister Plenipotentiary to Ankara, gives a lot of useful information about Albania-Turkey relations that had not been stumbled across in the literature until today. The aim of this study is to point out Atatürk's views on relations between Albania and Turkey, Albania and Italy, as well as his suggestions to Albanian envoy in Ankara about how to overcome the Albanian dependency on Italy. The research is based on the diaries of Fico, Albanian Minister Plenipotentiary to Ankara. The study is limited with focusing on the Italian factor in Albania's relations with Turkey rather than examining all aspects of the relationship between the two independent countries.

Fico had had formal education in the Ottoman Empire and occupied bureaucratic posts such as being provincial governor and following independence of Albania started to work for Albanian government as an important diplomat. Therefore, his diaries provide us a plenty of information on the question of Albania's relations with Turkey as well as with Italy, particularly between 1925 and 1928 during which there had been a Republican regime in Albania.

In fact, Fico's diaries give perfect information about close relations between Turkey and Albania and the importance given by Mustafa Kemal Atatürk on these relations at bilateral level, at least until the destruction of the Republican regime by Ahmet Zogu who would proclaim himself as the King of Albania in 1928. The content of the Fico's diaries are very rich in a way that they consist problems of Orthodox Albanians in Istanbul, positions of Albanians in Kosovo, the exchange of Albanian Chams, reforms in Turkey, assassination attempt to Atatürk in İzmir and main themes in Nutuk. It should be kept in mind that the scope of this study is confined, first, to suggestions of Ataturk to the Albanian government regarding getting rid of dependency on Italy, and second, to his foresight about Italy's position towards Albania and Turkey.In this respect, the Fico's diaries give invaluable information on all these subjects elaborated in this paper.
\end{abstract}

Keywords: Turkey, Albania, Rauf Fico, Diary, Dependency. 


\section{ANKARA ELÇİIİ RAUF FİCO'NUN GÜNLÜKLERİ IŞIĞINDA KRALLIK İLANI ÖNCESİ TÜRKIYYE-ARNAVUTLUK İLİSKIILERİNE ATATÜRK'ÜN YAKLAŞIMI}

\section{Giriș}

Arnavutluk, Osmanlı Devleti'nden 28 Kasım 1912'de ayrıldığında henüz sınır sorunlarını çözememişti. Bu nedenle Arnavutluk sınırları, 19131925 yılları arasında Büyükelçiler Konferansı'nda belirlenmeye çalıșıldı. Buna ilave olarak Osmanlı Devleti'nden ayrılıp bağımsızlığını kazandıktan sonra Arnavutluk, yine dışa bağımlı olarak kendi egemenlik hakkından mahrum durumda bırakıldı. Öyle ki ülkenin yöneticisini (kralını) bile büyük güçlerin izlemiş olduğu strateji belirlemişti.

Londra'da Büyükelçiler Konferansı'nda (17 Aralık 1912 - 11 Ağustos 1913) Arnavutluk'un bağımsızlı̆̆ı kesinleştikten sonra Ren Prusya'sında küçük bir prensliğin başında bulunan Prens Dö Vid'in kardeși Giyom-Frederik-Hanri dö Vid, büyük güçlerin ittifakıyla Arnavutluk'a kral olarak tayin edilmişti. Prens Vid, yaklaşık altı ay Arnavutluk tahtında kalmıștı. ${ }^{1}$

$\mathrm{Bu}$ durumuyla Arnavutluk, bağımsız ama egemenlik hakkını kullanamayan ve bağımlılığı tekrar yaratılan bir ülke konumunda iken, Türkiye, İstiklâl Savaşı sonucu bağımsızlı̆̆ını ve Lozan'da müzakereyle egemenlik hakkını elde ettiği için kendine olan öz güveni yüksek bir ülkedir. Tarihsel deneyime de sahip olan Türkiye, içeride kendi dinamiklerini harekete geçirerek, bağımsız bir devletin temelini atarken eş zamanlı olarak Lozan'dan kalan sorunlarını da güçler arasındaki çelişkileri kendi lehine çevirmek suretiyle çözmekten yanadır.

Türkiye-Arnavutluk ilişkilerinde ortaya çıkan çalışmalar, ilişkilerdeki gelgitlerin olduğu temasını işler ki bu doğru bir tespittir. Bunun sebebini 1925-1928 yıllarında Balkanlarda nüfuslarının çoğunluğu Müslüman ama Cumhuriyet rejimini belirlemiș olan liderlerin yaklaşımlarına da bakarak doğrulamak mümkündür. Öncelikle Türkiye, Lozan Antlaşmasını takiben yakın ve uzak komşularıyla olan ilişkilerini normalleşme sürecine sokmaya çalıştı. Bunu takiben bölgesel politikaları askerî ve diplomatik manevralarla kendi lehine çevirerek, dış güvenlik ağları oluşturmayı

${ }^{1}$ Halil Özcan, Atatürk Dönemi Türkiye-Arnavutluk İlişkileri (1920-1938), Atatürk Araştırma Merkezi, Ankara 2011, s. 22. 
hedefledi. Bunlara ilave olarak tehdit algılamasına karşı da uluslararası güvenlik ağı oluşturmayı gerekli gördü. ${ }^{2}$

Atatürk açısından Türkiye'nin güvenliği için Balkanların istikrarı ve sınırların değişmezliği önemliydi. Çünkü her hangi bir askerî çatışma Türkiye'nin kalkınması için kaynak tahsisi yapılmasını imkânsız hale getirebilir, modernleşme doğrultusunda atılacak adımları mümkün olmaktan çıkarabilirdi. Hatta Lozan kazanımlarına bile zarar verebilirdi. Ayrıca Balkanlar, Türkiye'nin, Trakya ve Boğazların güvenliği açısından son derece de önemliydi. Geçiş serbestisi için Lozan'a göre Boğazların askersizleştirilmesi, Çanakkale ile İstanbul Boğazlarının her iki kıyılarını, Marmara adalarını ve Çanakkale giriş noktasındaki Türk ve Yunan adalarını kapsamaktayd1. Buna göre; İstanbul'da 12.000 kişilik bir kuvvet bulundurulacaktı. $^{3} \mathrm{Bu}$ kuvvet, iç güvenlik için kullanılacağından ağır silahlardan yoksundu ve Türkiye'nin Boğazları ve İstanbul'u savunmasını imkânsız hale getirebilirdi. Türkiye'nin Balkan sınırlarına en yakın ağır silahlara sahip birliği Bursa'da bulunuyordu ve o tarihlerde Bursa'dan Trakya sınırına asker sevkiyatı bir haftayı bulabilirdi. Bu durum, güvenlik açısından ciddi zafiyet doğurmaktaydı. Aslında Boğazlarla birlikte Yunanistan ve Bulgaristan sınırının askerden arındırılmış olması, Türklerin karşılaştı̆̆ en ciddî savunma sorunuydu. ${ }^{4}$

\footnotetext{
${ }^{2}$ Mustafa Türkeş, “Atatürk Döneminde Türkiye'nin Dış Politikaları (1923-1938)”, Ankara Üniversitesi Siyasal Bilgiler Fakültesi, Uluslararası Atatürk ve Modern Türkiye Konferansi, 22-23 Ekim 1998, Ankara, s. 132.

${ }^{3}$ Hüseyin Tosun, "Montrö Boğazlar Sözleşmesi (Boğazlar Sorununda Son Aşama)", Ankara Üniversitesi Türk Inkılap Tarihi Enstitüsü Atatürk Yolu Dergisi, Say1: 13, 1994, s. 96-97. Lozan Boğazlar Sözleşmesi'ne göre, Çanakkale Boğazı, kuzeybatıda Gelibolu yarımadası ve Saroz Körfezi'nde, Bakla Burnu'nun kuzeydoğusundan dört $\mathrm{km}$. mesafede bulunan noktadan başlayarak Marmara Denizi'nde, Kumbağı'nda sona eren ve Kavak'ın güneyinden geçen bir çizginin güneydoğusundaki bölgeye kadar uzanan alanın askerden arındırılması kararlaştırıldı. Ayrıca, doğuda Karadeniz Boğazı'nın batı kıyısından 15 km. uzaklıkta belirlenmiş bir çizgiye kadar olan bölgenin de askerden arındırılması isteniyordu. Buna ilave olarak, Emir Ali Adas1 dışında kalan bütün Marmara Denizi adaları ve Ege Denizi'nde Semendirek, Limni, Bozcaada, ve Tarcan Adalarının da askerden arındırılması gerekiyordu. Sonuç olarak askerden arındırılan bölgeler 75 mil uzunluğunda, 3-15 mil genişliğindeki tarafsız bölgeyi oluşturmaktaydı. Buna ilave olarak, tarafsız bölge sınırları içerisinde hiçbir istihkâm, topçu, ışıldak tesisleri, denizaltı, hiçbir havacılık tesisi ve deniz üssü bulunmayacaktı. Selma Yel, Değişen Dünya Şartlarında Karadeniz ve Boğazlar Meselesi (1923-2008), Atatürk Araştırma Merkezi, Ankara 2009, s. 48. ${ }^{4}$ Mustafa Türkeş, "The Balkan Pact and Its Immediate Implications for the Balkan States 19301934”, Middle Eastern Studies, 30/1, 1994, p. 130.
} 


\section{ANKARA ELÇİSİ RAUF FİCO’NUN GÜNLÜKLERİ IŞIĞINDA KRALLIK İLANI ÖNCESİ TÜRKIYYE-ARNAVUTLUK İLIŞKILERINNE ATATÜRK'ÜN YAKLAŞIMI}

İtalya, I. Dünya Savaşı’nda Londra Gizli Antlaşmasıyla Türkiye'nin Batısı ve Akdeniz kıyılarına sahip olacaktı. Ancak Anadolu'nun paylaşım hesaplarında İtalya yerine Yunanistan'ın tercih edilmesi, İtalya'da politika değişikliğine ve Ankara ile yakın ilişki kurmasına yol açmıştı. ${ }^{5}$ Öte yandan 1922 y1lında Mussolini'nin iktidara gelmesiyle 12 Adalara da sahip olan İtalya'nın bu adalarla yetinmeyeceği ve Anadolu'dan toprak isteyeceği düşünülmekteydi. İtalya, Akdeniz'den Türkiye'yi tehdit edecek potansiyele sahipti. Ayrıca İtalya, Arnavutluk ve Bulgaristan ile yakınlaşmasıyla Balkanlar üzerinden de Türkiye'ye tehdit oluşturmaktaydı. Çünkü İtalya'nın Akdeniz'den ve Bulgaristan'ın eş zamanlı Balkanlardan gelecek saldırıları, Türkiye'nin savunma gücünü kolayca kırabilirdi. ${ }^{6}$ Boğazlar sözleşmesi nedeniyle bölgenin askerden arındırılması bu durumu daha da kolaylaştırmaktaydı.

Atatürk, gelişmeleri daha geniş bir açıdan soğukkanlı ve öngörülü bir şekilde değerlendiriyordu. Ona göre, Mussolini, Türkiye'ye karşı bir (askerî) harekâta karar verirse, önce Arnavutluk'a asker çıkaracak, sonra Bulgarlarla işbirliği yaparak, birlikte Boğazlara inmeye ve Balkan Devletleriyle Türkiye'nin ilişkisini kesmeye çalışacaktır. Atatürk'e göre, böyle bir saldırının başlangıç noktasını Avlonya oluşturabilirdi. ${ }^{7}$ Çünkü Avlonya'nın

5 Türkeş, “Atatürk Döneminde Türkiye'nin Dış Politikaları (1923-1938)”, s. 137.

${ }^{6}$ Türkeş, a.g.m., s. 135.

${ }^{7}$ II. Dünya Savaşı başladığında İtalya'nın Arnavutluk'u işgal etmesi Atatürk'ün öngörüsünü doğru çıkardı. Tanınmış Alman Balkanologlardan biri, II. Dünya Savaşı başlangıcında Arnavutluk hakkında yayınladığı tetkik eserinde de bu savı doğrulamaktadır. Yazar, Atatürk'ün Arnavutluk Cumhurbaşkanının kendisini Kral ilan etmesini komedilik olarak yorumlar ve şu değerlendirmeyi yapar: "Bunun Arnavutluk için doğuracă̆ neticelerin vahametini daha ilk gününde ve bütün fecaatiyle kavrayan tek adam, Atatürk olmuştur. Zog bu hatasının cezasını çekmekte gecikmedi: 7 Nisan 1939 sabahı, Mussolini'nin dişarıdan ve içeriden pek iyi hazırladı̆̆ taarruzuna uğrayarak, tek bir günde hem tahtından oldu, hem de memleketin bağımsızlığını faşistlere kaptırdı. Atatürk o hatânın işlendiği günün hemen akabinde bunun neye varacağını derhal anladı ve o zamanın diplomatik çevrelerinde hayret uyandıran bir jestle onu alenen cerh ve takbih etti. Fakat bu, sadece bir takbih değildi; ayn zamanda çok yerinde bir ikazdl. Ama ne çare ki bunun mânasını ne Zog'un kendisi ne de Avrupalı yorumcuların hiçbiri kavrayamadı". A. Baha Özler, "Yakın Tarihimizin Gizli Kalmış Tarafları: Atatürk'ün Arnavutluk Hakkında Siyasî Bir Kehaneti”, Tarih Dünyası Dergisi, Sayı: 35, 26 Kasım 1952, s. 1411. Ahmet Zogu da Atatürk'ün ikazlarını yeterince anlamış olsaydı, 8 Nisan günü ülkesini terk ederek Türkiye'ye sığınmak zorunda kalmazdı. Almanya'nın Ankara büyükelçiliği görevinde bulunan Von Papen, de İtalyanların Arnavutluk üzerinden Yunanistan'a baskın yapmasını, "Atatürk'ün öngörüsü hakikat oldu” şeklinde ifade etmiştir. Soyak'a göre Atatürk sağ olsaydı II. Dünya Savaşı başında İtalya'nın Arnavutluk’u işgalini bütün kuvvetiyle engeller ve İtalya, II. Dünya Savaşı'nda Balkanlara inemezdi. Hasan Rıza Soyak, Atatürk'ten Hatıralar, Yap1 Kredi Yayınları, 3. Bask1, İstanbul, Ocak 2006, s. 502-507. 


\section{HALİL ÖZCAN}

ağzındaki Sazan Adası, İtalyanların elinde tahkim ve sıçrama noktası haline gelmişti. Onun için Atatürk, Arnavutluk'un güvenliğini hem bu ülkenin güvenliği hem Balkanların ve Türkiye'nin güvenliği açısından son derece önemsemişti. ${ }^{8}$ Ona göre; İstanbul'un, Boğazların ve Türkiye'nin güvenliği Adriyatik'ten başliyordu.

Arnavutluk ise başta Kosova olmak üzere diğer ülkelerde yaşayan soydaşlarının durumlarıyla ilgileniyordu hatta onlarla birleşmeyi öngörüyordu. Bu konu, sorun yaratma ve çatışma çıkarma potansiyeline sahipti. Bu politikayı da kendi gücüne dayanarak yürütemeyeceğini bildiği için bir büyük devlete, İtalya'ya yaklaşıyordu. 1925-1928 y1llarında bunun ipuçlarını aşağıda ayrıntısı verilen Rauf Fico (Fico)'nun güncelerinden ${ }^{9}$ kısmen yakalamak mümkündür. Atatürk de Fico aracılığıyla İtalya'ya karşı pozisyon alınmasını Zogu'ya tavsiye ederek onu bizzat cesaretlendirmeye çalışmaktaydı.

Türkiye ile siyasî ilişkilerini geliştiren Arnavutluk, İtalya'ya iktisadî tavizler verdiği Tiran Dostluk ve Güvenlik Paktı'nı 27 Kasım 1926'da imzalamıştı. Çünkü Arnavutluk kaynaklarını kullanamıyordu ve sermayeye ihtiyacı vardı. Türkiye kıt kaynaklarını kendi kalkınmasına ayırdığı için Arnavutluk'a yardım edecek durumda değildi. O zaman Arnavutluk'un İtalya ile yakınlaşması daha ileri düzeye gidiyor ve Arnavutluk İtalya' ya yaklaştıkça Türkiye'den uzaklaşıyordu. Bu uzaklaşmanın sonucu olarak Arnavutluk Cumhurbaşkanı Ahmet Zogu, İtalya'nın desteği ile 1 Eylül 1928'de “Arnavutların Kralı" olacaktı.

Türkiye ile ilişkileri kopan ve Tiran Dostluk ve Güvenlik Antlaşması'nı imzalayarak İtalya'nın nüfuzu altına giren Arnavutluk, 9 Şubat 1934'te imzalanan Balkan Paktı'na giremeyecektir. Bulgaristan da İtalya'ya yaklaşarak revizyonist bir politika takip edecek ve Balkan Paktı'nın dışında kalacaktır. Balkan Paktı'ndan sonra Türkiye, Akdeniz'de güvenlik zafiyeti olduğuna, İngiltere ve Fransa'y ${ }^{10}$ da ikna ederek, Montrö Boğazlar

${ }^{8}$ Halil Özcan, "TBMM Hükûmeti İle Arnavutluk Hükûmeti Arasında İmzalanan Gizli Anlaşmanın Sebep Ve Sonuçları", İstanbul Gelişim Üniversitesi Sosyal Bilimler Dergisi, Cilt: 4, Say1: 2, Ekim 2017, s. 123-124.

${ }^{9}$ Rauf Fico'nun günlüklerinin Türkçe çevirisini büyük bir titizlikle yapan TRT Dıș Yayınlar Dairesi Arnavutça Masa Sorumlusu dostum, Serdar Hüseyni'ye teşekkürü bir borç bilirim.

10 İngiltere ve Fransa, İtalya'nın Akdeniz havzasında Almanya'nın önünü keseceği yanlış politikasından, bu ülkenin Habeşistan'1 işgal etmesiyle dönmesi durumudur. 


\section{ANKARA ELÇİIİ RAUF FİCO'NUN GÜNLÜKLERİ IŞIĞINDA KRALLIK İLANI ÖNCESİ TÜRKIYYE-ARNAVUTLUK İLIŞKILERINNE ATATÜRK'ÜN YAKLAŞIMI}

Sözleşmesiyle (20 Temmuz 1936), Boğazlar ile birlikte Yunan ve Bulgar sınırına asker yerleştirerek güvenlik zafiyetini ortadan kaldırmayı başardı.

Atatürk'ün Arnavutluk ile kurmaya ve geliştirmeye çalıştığı ilişkiye bakarak, Osmanlıya tamamen sırtını dönmediğini, onu yok saymadığını ve Osmanlı'da yetişmiş bir bürokrat üzerinden ilişkiyi tesis etmeye çalıştığını söylemek mümkündür. Hatta Osmanlı İmparatorluğu'ndan geriye kalan devletlerle ilişkileri örerek, bölgesel paktlar kurmayı amaç edindiği somut bir gerçektir. Ama bu ilişkiyi örerken teorik olarak karşısındakini bağımsız bir aktörün temsilcisi olarak kabul ediyor ve çok daha yakın bir ilişki kurmaya gayret ediyordu. Türkiye'nin Cumhuriyet'in ilanından sonra ilk dostluk anlaşmasını Arnavutluk ile imzalaması da Balkanlarda Arnavutluk'u dışlamak değil, aksine tam da stratejinin ortasına almak istediği şeklinde değerlendirilebilir. ${ }^{11}$ Atatürk'e göre Arnavutluk'un bağımsız bir devlet olarak kuvvetlenip ilerlemesi, tüm Balkanların geleceği açısından önemli olduğu için bu ülke ile Türkiye'nin yakın işbirliği içerisinde olması gereklidir. ${ }^{12}$ Ancak Arnavutluk temsilci ve yöneticilerinin bu durumu yeterince kavrayamadıkları görülmektedir.

Fico'nun günlüklerinde verdiği bilgilere bakıldığında Arnavutların, aslında Ankara'da uygulamaya konulan yeniden yapılanma politikasından etkilendiği görülür. Aynı zamanda Mustafa Kemal Paşa'nın da Arnavutluk yöneticilerine tavsiyelerde bulunarak kendisinin tehdit olarak gördüğü İtalya'ya karşı Arnavutluk ile stratejik ilişkiler kurmaya çalıştığı dikkat çekmektedir. Bu bağlamda Arnavutluk'un Ankara'ya atadığı Elçisi Rauf Fico'nun güncesi, ülkesinin Cumhuriyet rejimine geçtiği bir dönemde birlikte, İtalya'ya iktisadî ve askerî bakımdan bağımlı hale geldiği bir zaman dilimine 1şık tuttuğu için de kıymetlidir.

\section{Arnavutluk Cumhuriyeti’nin İlk Elçisi Rauf Fico}

Abdurrahman Rauf Fico, 13 Mart 1881'de Yemen Sana'da dünyaya geldi. Ancak bazı kaynaklarda doğum yeri olarak Ergiri’yi vermektedir. İlk

\footnotetext{
${ }^{11}$ Hatta Arnavutluk’ta 1 Eylül 1928 günü Krallık ilan edildiğinde, Arnavutluk Kralını halkına ihanet ettiği gerekçesiyle tanımadı ve derhal Arnavutluk’ta görev yapan Türkiye Elçisi Tahir Lütfi Bey'i Ankara'ya çağırdı. Ancak Arnavutluk'u Balkan Paktı'na dahil edebilmek için II. Balkan Konferansı'nın Türkiye'de yapılmasını firsat olarak değerlendirerek, tüm Balkan Devlet Başkanlarına ve Arnavutluk Kralına telgraf çekmek suretiyle ilişkileri yeniden başlattı, Özcan, a.g.e, s. 203-215, s. 267.

12 Özcan, a.g.e., s. 59.
} 


\section{HALİLÖZCAN}

eğitimini İşkodra mektebinde tamamladıktan sonra Viyana'da Volksschule'de iki yıl okudu ve liseyi İstanbul'da bitirdi. ${ }^{13}$ İstanbul Mülkiye Mektebi'nde kamu yönetimi okuyarak çok iyi derece ile mezun oldu. Sürekli özel öğretmenlerden ders aldığı için literatüre hâkimdi ve çok iyi yabancı dil (Türkçe, Farsça, Fransızca, Yunanca, Arapça, İtalyanca ve Almanca) biliyordu. Temmuz 1903'te mezuniyeti sonrası Yanya Valiliğinde 1906 yılına kadar staj yaparak kaymakamlık unvanı aldı. Sonra sirasıyla Konica (1906), Himara (1909), Margılıç (1910) kaymakamlığı görevlerinde bulundu. Kayseri valiliğindeki (yıl) görevinden sonra 1912 y1lı sonlarında Arnavutluk'un bağımsızlı̆̆ıyla ülkesine döndü. ${ }^{14}$

Arnavutluk'un bağımsızlığından sonra İsmail Kemal'in kurduğu ilk hükümette İçişleri Bakanlığına danışman olarak atandı. 1913 yılı yazında Avlonya Hükümeti heyetinin üyesi olarak, Arnavutların ulusal haklarını korumak için Roma ve Viyana'ya gönderildi. 1913 yılı sonbaharı ile 1914 yılı Mart aylarına kadar Berat Valisi olarak görev yaptı. Alman Prens Vid, Arnavutluk'a kral olarak gönderildiğinde Turhan Paşa Hükümetinde Başbakanın özel kalem müdürü oldu. Avusturya-Macaristan işgaline kadar bu görevde kaldı. Luşnya Kongresine kadar (Ocak 1920'ye kadar) Tiran Kaymakamlığ görevini yaptı. Süleyman Delvina Hükümetinde İçişleri Bakanlığında daire başkanı olarak görev yaptıktan sonra Ahmet Zogu Hükümetinde İçişleri Bakanı oldu. Draç mebusu olarak Arnavutluk Meclisine girdi. Arnavutluk'ta Krallık ilan edildikten sonra Dışişleri Bakanı oldu ve 23 Ocak 1944'te hayatını kaybetti.

\section{Rauf Bey’in Elçilik Süreci}

Rauf Bey'in 1912'de Arnavutluk'a dönmesinden sonra TürkiyeArnavutluk anlaşmalarının onaylı suretlerinin teatisi için Türkiye'ye görevlendirilmesi gündeme geldi. Rauf Bey, 11 Nisan 1925 günü Arnavutluk Maliye ve Dışişleri Bakanı Müfit Libohova ile Ankara'ya gidişini görüştü. Rauf Fico, Türkiye'ye gitme konusunda istekli olmalı ki görüşmeden sonra, "Müfit de Başkan (Cumhurbaşkanı) ile görüşüp bilgi vereceğini söyledi" cümlesini günlüğüne not etti. ${ }^{15}$ Rauf Bey, 16 Nisan günü Cumhurbaşkanı

\footnotetext{
${ }^{13}$ Shqyr1 Hys1, Rauf Fico Shtetar Dhe Diplomat I Shquar (Monografi), Tiranë 2007, s. 27-28.

14 Cumhuriyet Gazetesine göre Fico, Kangal ve Kizılcahamam (1910) Kaymakamlığ görevlerinde de bulundu (4 Mayıs 1925, s. 1).

${ }^{15} 11$ Nisan 1925,jpg 52-1. Rauf Fico'nun günlükleri ait olduğu gün ve y1lın ajanda sayfalarına yazılmıştır. Sonradan elektronik ortamda jpeg formatında iki gün (bir jpeg sayfası) olarak
} 


\section{ANKARA ELÇİIİ RAUF FİCO'NUN GÜNLÜKLERİ IŞIĞINDA KRALLIK İLANI ÖNCESİ TÜRKIYYE-ARNAVUTLUK İLIŞKILERINNE ATATÜRK'ÜN YAKLAŞIMI}

Ahmet Zogu tarafindan sıcak bir ilgiyle karşılandı ve Ankara'da konuşulacak konular ele alındı. ${ }^{16} 18$ Nisan'da binbir güçlükle Dışişleri Bakanlığından Ankara'ya gidişle ilgili işlemlerini tamamladı. ${ }^{17}$

Arnavutluk'taki bürokratik ișlerini tamamladıktan sonra Arnavutluk Meclis üyesi Cemal Efendi ${ }^{18}$ ile 20 Nisan'da Tiran'dan Draç'a hareket etti ve akşam Belgrad vapuruna bindi. ${ }^{19}$ Eski bir Türk bürokratı olan Rauf Bey, İstanbul'a geldiğinde Cumhuriyet Gazetesi muhabirine oldukça gelişmiş bulduğu Türkiye'de bulunmuş olmanın mutluluğunu ifade etti. Rauf Bey'e göre Arnavutluk halk1, Türkiye ve Türklere karşı çok derin ve kadim dostluk bağıyla bağlı olduğu için Türk bağımsızlık hareketinin zaferle sonuçlanmasından bizzat Türkler kadar kendilerini mesut kabul etmiştir. Ayrıca Arnavutlar, Türkiye'deki laikliği ve reformları da memnuniyetle karşılamışlardır. ${ }^{20}$

Rauf Bey'in Türkiye elçisi olarak atanması konusu, kendisi Ankara'ya Türkiye-Arnavutluk antlaşmalarının teatisi için geldiğinde gündeme geldi. İstanbul'dan Ankara'ya gelişinde Haydar Paşa Garı'ndan Ankara'ya (23 Mayıs günü) hareket etti. Günlüğüne Vatan Gazetesinin kendisi hakkında "ileride Arnavutluk'un Türkiye elçisi olacak" ${ }^{21}$ diye yazdığı, notunu düştü. Yaklaşık bir buçuk aylık Türkiye görevini takiben ülkesine döndükten sonra Arnavutluk'taki gelişmelerden haberdar oldu. Bu kapsamda Cemil Dino'nun Roma'ya (elçi olarak) gideceğini ve Cafer Üpi (Xhafer Ypi) Türkiye'ye elçi olma teklifini kabul ettiğini öğrendi. ${ }^{22}$ Hemen harekete geçerek Cumhurbaşkanı Zogu'dan randevu aldı ve ona Ankara konusunu açarak, elçi olarak atanabilmek için onun desteğini aradi. ${ }^{23}$ Böylece de Cafer Üpi'nin Ankara elçiliğini boşa çıkardı.

fotoğraflanmıştır. Atıflarda kullanılan günlükler, günü ve elektronik ortamdaki fotoğraf numaralarıyla (aynı sayfadaki günler 1 ve 2 olarak) birlikte verilmiştir.

1616 Nisan 1925, jpg 54-2.

${ }^{17} 18$ Nisan 1925,jpg 55-2.

1815 Mart 1919'da İstanbul'da kurulan Arnavut Teavün Cemiyeti'nin kurucularından olan Cemalettin Efendi, 1924 yılının sonlarına kadar İstanbul Fatih-Zincirlikuyu'da Kesme Kaya Mahallesi imamlığı yaptı. Arnavutluk'a izinli olarak gitti ve Türkiye'de kalan bir kısım maaşını da alabilmek için müracaatta bulundu, Tanin, 28 Mart 1925, s. 1; Özcan, a.g.e., s. 148.

${ }^{19} 20$ Nisan 1925, jpg 56-2.

${ }^{20}$ Özcan, a.g.e., s. 152.

${ }^{21} 23$ Mayis 1925,jpg 73-1.

2224 Haziran 1925, jpg 105-2.

${ }^{23} 28$ Temmuz 1925, jpg,107-2. 


\section{HALİL ÖZCAN}

4 Ocak 1926 günü öğleden sonra Cumhurbaşkanı ile görüşmesinde Ahmet Bey ona Ankara elçiliğini teklif etti ve o da kabul etti. ${ }^{24} 5$ Ocak günü Arnavutluk Dışişleri Bakanlığı, İstanbul Konsolosluğu ile temasa geçerek Arnavutluk'un Ankara'ya elçi atama isteğinde bulunduğunu bildirdi ve bunu Ankara'ya ileterek, cevabindan Tiran'1 bilgilendirmesi istendi. ${ }^{25}$ Rauf Bey, beklediği Elçilik cevabı geciktiği için günlüğüne, "Ankara'dan haber gelmedi" $^{26}$ diye yazdi.

15 Ocak günü (İzzeddin Beşiri'den) İstanbul'dan (Elçilik konusunda) olumlu cevap geldiğini ve Türkiye'nin (Elçiliği) sevinçle karşıladığını öğrendi. ${ }^{27}$ Ertesi gün, bakanlar kurulunda Rauf Bey'in Angora'ya (Ankara) Elçi olarak atanması ile ilgili teklif, kabul edildi. ${ }^{28}$ Ahmet Zogu da 17 Ocak 1926 günü Türkiye Cumhuriyeti Cumhurbaşkanı Gazi Mustafa Kemal Paşa'ya yazdığı mektupta, Rauf Fico'yu Arnavutluk Cumhuriyeti'nin "Fevkalâde Murahhas ve Orta Elçisi" unvanıyla tayin ettiğini bildirdi. ${ }^{29}$ Fico, 7 Şubat saat 07.15'te Tiran'dan Draç'a hareket etti ve gümrükten nakit olarak paralarını çekti. Akşamüstü vali ve üst düzey görevliler Rauf Bey'i uğurlamak için geldi. Akşam saat 8'de kötü bir havada vapur hareket etti ancak gece firtına daha da kuvvetlendi. Gece yarısında yağmur yağdı ve hava yumuşadı ve sabah saat 8 'de Bari'ye geldi. ${ }^{30}$

Bari'deki Türk Konsolosunu ziyaret etti ve günlüğüne "(Konsolos için) çok yumuşak ve uslu bir adam" diye yazd $1 .{ }^{31}$ Saat 2.30 'da Brindizi'den

24 Ocak 1926, jpg 3-1.

255 Ocak 1926, jpg 3-2.

${ }^{26} 13$ Ocak 1926, jpg 7-2.

${ }^{27} 15$ Ocak 1926, jpg 8-2.

${ }^{28} 16$ Ocak 1926,jpg 9-1.

${ }^{29}$ Bilâl, N. Şimşir, Atatürk ve Yabancı Devlet Başkanları C. I, Türk Tarih Kurumu, Ankara, 1993, s. 286.

307 Şubat 1926, jpg 20-2.

319 Şubat 1926, jpg 21-2. 


\section{ANKARA ELÇİSİ RAUF FİCO’NUN GÜNLÜKLERİ IŞIĞINDA KRALLIK İLANI ÖNCESİ TÜRKIYYE-ARNAVUTLUK İLİSKIILERİNE ATATÜRK'ÜN YAKLAŞIMI}

hareket edip 13 Şubat'ta Pire'ye geldi ve Arnavutluk Atina Elçisi Mithat Fraşheri ile Çameryalılar ${ }^{32}$ konusunu görüştü. $^{33}$

14 Şubat Pazar günü İstanbul'da Vali Süleyman Sami, Hükümet temsilcisi Nazmi Bey motorla giderek, gemide Arnavutluk elçisini karşıladılar. Limanda ise bir grup Arnavut ile fotoğrafçılar onları bekliyordu. Karşılamadan sonra, Arnavutluk Konsolosluğunda kendisini bekleyen Arnavutlarla görüştü. Geceyi Tokatlıyan Otelinde geçirdi ve "oda kötüydü uyuyamadım" "34 diye not düştü. Ertesi gün, vali ve Dışişleri Bakanlığı siyasi temsilcisini ziyaret etti. Tüm Arnavutların elçiye yapılan karşılamadan dolayı memnun olduklarını öğrendi. Bazı gazetelerin gelişini fotoğraflı haberlerle verdiğini gördü. ${ }^{35}$

21 Şubat günü İstanbul Arnavutluk Konsolosu Nusret Bey ile birlikte Vali’ye veda ziyaretine gitti. Ertesi gün Ankara'ya gitmek üzere Haydar Paşa Garı'ndan yola çıtı. ${ }^{36} 23$ Şubat günü saat 10.30 'da Ankara Garı'nda Saffet, Ziya Bey ve hükümet görevlileri tarafindan karşıland1. Günlüğüne "Türk Ocăğndan dostlar gibi kalktık" diye yazdı. Ertesi gün akşam üzeri saat 5'te D1şişleri Bakanı ile görüşeceği bildirildi. ${ }^{37}$ "Günlüğüne Ankara çok ilerlemiş. Gerçekten neredeyse Avrupalı bir şehir gibi olmuş" diye not düştü.

Rauf Bey, Türkiye Cumhurbaşkanı Gazi Mustafa Kemal Paşa'ya itimatnamesini sunmadan önce 8 Mart 1926 günü öğleden sonra Türkiye

\footnotetext{
${ }^{32}$ Epir bölgesinde bulunan Çamerya veya Yunan halkının deyişiyle Thesprotia, İyon Denizi kıyılarından başlayarak doğuda İyonya dağlarına ve güneyde Preveze körfezine kadar uzanan bölgeye verilen isimdir. Kendilerinin İliryalı atalarından geldiklerini kabul eden buradaki Arnavut nüfus, bu bölgenin yerlisidir. Bir diğer önemli Arnavut nüfus ise Kalamit Nehri'nin her iki yakasına kurulmuş olan kasaba ve köylerde yaşayanlardan oluşmaktadır. Bu bölgede I. Dünya Savaşı öncesi nüfusun \% 93'ünü Arnavutlar oluşturmakta iken Müslüman Arnavutların bölgeyi terk etmek zorunda kalması sebebiyle savaş sonrası Arnavut nüfus oranı \% 50'ye kadar inmiştir. Yunanistan, Lozan'da imzalanan Mübadele Sözleşmesine aykırı olarak burada yaşayan Müslüman Arnavutları da mübadeleye dâhil ederek Türkiye'ye göndermek istemiştir, Bu konuda daha ayrıntılı bilgi için bakınız Halil Özcan, "Lozan Konferansı Tutanakları ve Arnavutluk'un Atina Büyükelçiliği Raporları Temelinde Mübadelede Yunanistan'daki Müslüman Arnavutların Durumu”, Hacettepe Üniversitesi Atatürk İlkeleri ve İnklâp Tarihi Enstitüsü Cumhuriyet Tarihi Araştırmaları Dergisi (CTAD), Ankara, Y11: 13, Sayı: 25, Bahar 2017, s. 50-79.

${ }^{33} 13$ Şubat 1926,jpg 23-2.

3414 Şubat 1926,jpg 24-1.

3515 Şubat 1926,jpg 24-2.

${ }^{36} 22$ Şubat 1921,jpg 28-1.

3723 Şubat 1926,jpg 28-2.
} 
Cumhuriyeti Dışişleri Bakanı Tevfik Rüştü Bey ile bir buçuk saat süren bir görüşme yaptı. 9 Mart 1926 günü öğleden sonra güven mektubunu sunmak için kabul edileceği haberini aldı ${ }^{38}$ "Mustafa Kemal Paşa'nın hasta olması nedeniyle bugün (9 Mart) kabul olunmayacağ l" bilgisini aldı ve üzüldü. ${ }^{39} \mathrm{Bu}$ engeli (rahatsızlık) "Epir (Çamerya) konusunu konuşmak istemedikleri için mi yapıyorlar?" diye yorumladı ve şüpheye düştü. ${ }^{40}$ Nihayet 13 Mart Cumartesi günü (öğleden sonra) saat 15:00’te Mustafa Kemal Paşa tarafindan kabul edileceğini öğrendi. Tesadüf müdür bilinmez ama o gün aynı zamanda Rauf Fico'nun doğum günüydü.

\section{Gazi Paşa'ya Güven Mektubu}

13 Mart 1926 Cumartesi günü öğleden sonra saat 15:00'te Gazi Mustafa Kemal Paşa'nın bulunduğu salona girdi. Rauf Bey, güven mektubunu takdimi sırasında Arnavutluk Cumhurbaşkanının kendisine bu yüksek ve nazik görevi verirken geçmişte müşterek mukadderata sahip olan iki millet arasında asırlardır var olan dostluk ve güveni tasdik için bütün kuvvetiyle çalışmasını tavsiye ettiğini söyleyerek konuşmasına başladı. Devamında Arnavutluk'un ilk elçisi olmasi sebebiyle duyduğu mutluluğu ifade ederek, iki ülkenin menfaatine ve iki dost millet arasındaki sıkı ilişkinin devamına çalışacağını söyledi. Rauf Bey konuşmasını şöyle tamamladı: ${ }^{41}$ “...Asil Türk milletinin rahat ve ikbali ve zatı şahanelerinin saadeti için hararetli münasebet dermiyan ederken (ortaya koyarken) zatı şahaneleri ve muhterem Hükûmeti tarafindan memur etmek müntiç olmasina (muafakiyet sebebi olan) muktezi klymetli (klymet gerektiren) ve müessir (tesir eden, iz bırakan) muzaheret (görünen) kanaatinde bulunduğunu beyan ederim".

Rauf Bey, konuşmasını yaptıktan sonra Gazi Mustafa Kemal Paşa, kısık ve hasta bir sesle cevap verdi. Çünkü Gazi'nin üşütme neticesinde sesi kısılmıştı ve rahatsızlığına rağmen Arnavutluk Elçisini kabul ediyordu. ${ }^{42}$ Gazi Paşa, Rauf Bey'e Arnavutluk'un genel olarak durumunu sordu. Rauf Bey de ülkesinde asayişin sağlandığını ancak ekonomik kalkınmayı sağlamak için 12.000 kişinin çalıştığını, bayındırlık ve iskân için 50 milyon altın frank borç aldıklarını söyledi. ${ }^{43}$

\footnotetext{
387 Mart 1926, jpg 35-1.

399 Mart 1926, jpg 36-1.

${ }^{40} 10$ Mart 1926, jpg 36-2.

${ }^{41}$ Özcan, a.g.e., s. 154

42 Özcan, a.g.e., s. 154.

${ }^{43} 13$ Mart 1926,jpg 38-1 (EK-1).
} 


\section{ANKARA ELÇİSİ RAUF FİCO’NUN GÜNLÜKLERİ IŞIĞINDA KRALLIK İLANI ÖNCESİ TÜRKIYYE-ARNAVUTLUK İLIŞKILERINNE ATATÜRK'ÜN YAKLAŞIMI}

Elçiye cevap olarak, Gazi Mustafa Kemal Paşa, Arnavutluk Cumhurbaşkanının zatıâlilerinin nezdinde fevkalade delege ve ortaelçi tayin ettiğini bildiren itimatnameyi memnuniyetle aldığını bildirdi. Sonra, Türklerin ve Arnavutların tarihî bağlarına dikkat çekerek, bunun iki memleket yararına daha sağlam temelli işbirliğine dönüştürmek gerektiğini belirtti. Elçiyi yüreklendirerek, ondan beklentilerini de dile getirecek biçimde kısa ve çarpıcı olarak: "Tarihin hayli uzun devrelerinde birçok sahalarda kader birliği yapmış olan iki millet arasındaki dostluk bağlarını sağlamlaştırmak suretiyle iki memleketin menfaatlerine hizmet etmek ve iki dost millet arasinda sıkı bir işbirliği devresi açmak hususunda vaki olacak mesainizin benim ve Cumhuriyet hükümetinin desteğine mazhar olacă̆ına emin olabilirsiniz" dedi. Bu cümlenin devamında elçiye Arnavutluk'un ilk temsilcisi olarak tayinin memnuniyetle karşıladığını ifade etti. Türk milletinin refah ve geleceğine ve şahsına söylediği beyanından dolayı teşekkür etti. Daha sonra Gazi, Elçi'ye Arnavutluk Cumhurbaşkanının saadeti ve Arnavutluk'un refah ve ikbali hakkındaki samimi duygularını beyan ederek, "hoş geldiniz" dedi ${ }^{44}$ ve kısa sohbetten sonra Rauf Bey kabul salonundan dişarı çıtı.

Fico, akşam günlüğune "İstiklâl marşı müziği çaldiğında gerçekten heyecandan tüylerim diken diken oldu" diye notunu düştü. Ayrıca Atatürk'ün kendi üzerindeki etkisini de defterine "Gazi bende Bonapart izlenimi biraktt. Onun duruşu Bonapart'in duruşu gibiydi" cümleleriyle not etti. Cumhurbaşkanına güven mektubunu sunduktan sonra, Başbakanı ve Dışişleri Bakanını ziyaret etti. ${ }^{45}$ Artık fiilî ve hukukî olarak elçi görevine başlamıştı.

\section{Gazi ile SSCB Elçiliğinin Ziyafetinde Musul Konusu}

\section{Hakkında Görüşme}

Sovyet Sosyalist Cumhuriyetler Birliği (SSCB) Sefaretinin açı1ışı nedeniyle 19 Nisan 1926 günü verilen ziyafete Arnavutluk Elçisi Rauf Bey de katıld. Türk-Rus dostluğunun bir sonucu olarak kabul edilen töreni, Gazi Mustafa Kemal Paşa da şereflendirdi. Gazi, Moskova'dan özel olarak konser için gelen kemancı Befinder'in konserinden sonra sanatçıya iltifat ederek; "kalplerinde, ruhlarında, hissiyatlarında inkılâp yapamayanlar dünyada hiçbir inkılâp yapamazlar" dedi. ${ }^{46}$ Rauf Bey de Prof. Befinder'den çok etkilendi. Henüz güven mektubunu sunmasının üzerinden beş hafta geçmiş

\footnotetext{
${ }^{44}$ Atatürk'ün Bütün Eserleri (1925-1927), Cilt: 18, Kaynak Yayınları, İstanbul 2006, s. 156.

45 13 Mart 1926, jpg 38-1.

${ }^{46}$ Atatürk'ün Bütün Eserleri, s. 178.
} 


\section{HALİL ÖZCAN}

olan Rauf Bey gündemdeki Musul konusunu açtı ve İsmet Paşa'ya, " $b u$ işe bir son verin bu dünya için iyi olacaktır" dedi.

Sonra, Dışişleri Bakanı Tevfik Rüştü Bey'e, “Íngilizlerle aranızı düzeltin" tavsiyesinde bulundu. İsmet Paşa ve Tevfik Rüştü Bey'in kendi düşüncesine yakın olduğunu hissetti. ${ }^{47}$ Günlüğüne, Gazi (Mustafa Kemal Paşa) benimle üç kez bir araya geldi ve "birincisinde Musul hakkında görüştük, ben de uzlaşma ve barış ile ilgili bir söz söyledim" diye yazdı. Gazinin verdiği cevabı da "ilkeyi koruyacă̆ız fakat ilke içerisinde mümkün olan her şeyi yapacağı" ${ }^{38}$ diye günlügüne not etti. ${ }^{49}$ Arnavutluk Elçisi, Türkiye için hassas olan bir konu olan Musul'a neden ilgi duymuştu?

Lozan'da sonuca bağlanamayan Musul konusunun çözümü için Türkiye ve İngiltere arasında 19 Mayıs 1924'te İstanbul'da görüşmeler başlamış ancak bir sonuç alınamadan 5 Haziran 1924'te kesilmişti. Misak-1 Millî sınırları içerisinde yer alan Musul için Türk ordusunun kullanılması kararlaştırılmış ancak bunu öğrenen İngiltere, Hakkari'deki Nasturîleri ayaklandırarak girişilecek askerî hareketi geciktirmeye çalışmıştı. Ayaklanma hemen bastırılmasına rağmen Musul sorunu uluslararası kurula havale edilmişti. Kurul da Hakkari'yi Türkiye'ye, Musul'u da Irak'a bırakan haksız bir karara imza atmıştı. Türkiye, bu haksız karara karşı Türk-İngiliz savaşını bile göze alarak sert tepki göstermiş ancak İngiltere'nin kışkırtmasıyla Şeyh Sait isyanı çıktığı için 1925 senesi bu isyanı bastırmakla geçmişti.

Milletler Cemiyeti Milletlerarası Daimî Adalet Divanı, Lozan Antlaşmasına göre, 21 Kasım 1925'te Musul konusunda bağlayıcı karar aldı. 16 Aralık 1925 'te Türkiye'nin katılmadığı toplantıda Milletler Cemiyeti de divanın Musul'u Irak'a bırakma kararını kabul etti. Türkiye bu kararı, büyük bir tepkiyle karş1layarak Cenevre temsilcisini geri çekti ve bir gün sonra 17 Aralık 1925'te Sovyet Sosyalist Cumhuriyet Birliği ile Dostluk ve Tarafsızlık Antlaşması imzaladı. Ayrıca Türk kamuoyunda İngiltere aleyhinde oluşan tepkinin bir sonucu olarak Türkiye'deki İngiliz şirketlerinin çoğu işlerini tasfiye etmek zorunda kald.$^{50}$ Arnavutluk Elçisi, Türkiye'nin karar vericilerine Türk politikasına ters düşecek ve İngiliz politikasını

\footnotetext{
47 Nisan 1926,jpg 57-1.

${ }^{48}$ Parantezler Rauf Bey'e ait.

4919 Nisan gününde yer olmadığı için ajandaya (devamı) Mart ayının not sayfası diye yazdı ve not almaya devam etti (Note, Jpg 47-2).

50 Sezen Kilıç, "Musul Sorunu ve Lozan”, http://www.atam.gov.tr/dergi/sayi-71/musulsorunu-ve-lozan, (18.08.2018).
} 


\section{ANKARA ELÇİSİ RAUF FİCO’NUN GÜNLÜKLERİ IŞIĞINDA KRALLIK İLANI ÖNCESİ TÜRKIYYE-ARNAVUTLUK İLIŞKILERINNE ATATÜRK'ÜN YAKLAŞIMI}

destekleyecek şekilde Musul konusunda tavsiyelerde bulunuyordu. Sonunda Musul, 5 Haziran 1926'da İngiltere ile imzalanan anlaşma sonucunda Irak'a bırakıldı. Türkiye, Musul konusuyla ilgilenirken İtalya da İngiltere’ye destek vermekteydi. Mussolini yönetimindeki faşist İtalya, Türkiye'nin Musul'u kuvvet kullanarak almaya kalkışması halinde, kendilerinin de Anadolu'ya asker çıkaracakları tehdidinde bulunarak ${ }^{51}$ İngilizleri rahatlatıyordu. Ayrıca, İtalya, Türkiye'nin Akdeniz ve Balkanlarda kendisini engellemesinin önüne İngiltere desteğiyle geçmek istiyordu.

Arnavutluk ise bu dönemde İtalya ile geri dönülemeyecek bir ittifakın görüşülmesi sürecindeydi. İtalya, Arnavutluk'taki iktisadî ve siyasî girişimlerini bir adım ileriye taşıyarak, Arnavutluk'u tamamen nüfuzu altına alabilmek için 24 Haziran 1926 tarihinde Tiran'daki Elçisini, Cumhurbaşkanı Ahmet Zogu'ya gönderdi. İtalyan Elçi, Arnavutluk'un güvenliğini sağlama görevi verilen İtalya'nın bu görevi silahla yerine getirmesini bir anlaşmaya bağlamayı teklif etti. Sefir, Ahmet Zogu'ya teklifinin kabul edilmemesi halinde bölünen ve parçalanan bir Arnavutluk için Roma'nın Belgrad ile anlaşacağı ve bir isyan olduğunda Arnavutluk Hükûmetinin kendi yetkilerini kullanmaya imkân bulamayacağı tehdidinde bulundu. A. Zogu da bu durumdan tereddütte düşerek İngiltere sefirine akıl danışmak mecburiyetinde kald1. ${ }^{52}$ Türkiye'nin Musul konusu İngiltere ile karar aşamasındayken Arnavutluk'un da İtalya'nın yerine İngiltere'nin desteğini almak için çaba sarf ettiği anlaşılmaktadır. Musul konusunda İngiltere'ye verilen desteğin karşısında, İngiltere'nin Arnavutluk'a yardımı umulmakla birlikte bu konuda İngiltere'yi destekleyen İtalya da mutlu edilmeye çalışılmaktayd.

Baloda bulunan İngiliz Büyükelçiliğinden I. Katip de Rauf Bey’in Musul konusunda Türkiye Cumhuriyetinin Cumhurbaşkanı, Başbakanı ve Dışişleri Bakanı ile olan görüşmelerine tanıklık etti. Ertesi gün bu destekten dolayı İngiltere Büyükelçisi Ronald Lindsay Rauf Bey'i davet ederek kendisine samimi bir yakınlık gösterdi ve "Türklere, (Musul konusunda) anlaşmazlı̆̆a son vermesi ile ilgili bulunduğu tavsiyeler" için teşekkür etti. ${ }^{53}$

20 Ağustos 1928 günü Fico'nun günlüğüne düştüğü notlar, Musul konusunda Arnavutluk'un İngiltere'ye olan desteği hakkında ipuçları

\footnotetext{
${ }^{51}$ Emine Kısıkl1, "Yeni Gelişmelerin Işı̆̆ında Geçmişten Günümüze Musul Meselesi," Ankara Üniversitesi Türk Inkılâp Tarihi Enstitüsü Atatürk Yolu Dergisi, Say1: 24, Kasım 1999-2003, s. 517.

52 Özcan, a.g.e., s. 184-185.

${ }^{53} 20$ Nisan 1926, jpg 57-2.
} 
vermektedir. Çünkü Fico, güncesine; "bugün İngiltere Büyük Elçisi, Edmond isimli birisini gönderdi. Bu şahıs bizim Elçiliğimiz sizin Irak (Musul) konusunda yaptıklarınızı unutmayacaktır" ve "Büyük Elçi seni yarın öğlen yemeğine davet ediyor" dediğini yazmaktadır. ${ }^{54}$ Rauf Bey'in yazdıklarından yola çıkarak kendisinin Musul konusunda İngiltere'den gelen bir talebi yerine getirmiş olduğunu ya da İngiltere'nin Arnavutluk'a yardımını sağlamak amacıyla konuyu Türk yetkililerine açtığını veya İtalya'nın tavsiyesi üzerine böyle bir girişimde bulunmuş olabileceğini söylemek de mümkündür. Zira burada Arnavutluk ve Rauf Bey için en önemli mesele İtalya'dan gelecek mali destektir.

Musul gibi hassas bir konuda, Rauf Bey'in İngiliz yanlısı tekliflerine Türk temsilcilerinin tepki vermemesini, Rauf Bey'e ve onun şahsında Arnavutluk'a önem verilmesinin bir göstergesi olarak da değerlendirmek mümkündür. Ancak bu konuda Türk tarafının kuşkucu ve temkinli olduğunu da hatırda tutmakta fayda vardır.

\section{5. Çocuk Esirgeme Kurumu Balosunda Gazi'nin Tiran Dostluk ve Güvenlik Paktı ile İlgili Mesajı}

İngiltere'den beklediği desteği bulamayan Arnavutluk, 27 Kasım 1926'da, İtalya ile Tiran'da Dostluk ve Güvenlik Paktı'nı imzalamak mecburiyetinde kaldı. Rauf Bey, ${ }^{55} 24$ Şubat 1927'de Amerika Birleşik Devletleri Temsilcisi Bristoli ile akşam yemek yedikten sonra, Ankara Palas'ta "Çocuk Esirgeme Kurumu" balosuna ${ }^{56}$ katıldı. Baloda Gazi Mustafa Kemal Paşa, Arnavutluk Elçisini yanına çağırarak, diğer davetlilerin ve elçilerin duyacağı şekilde Arnavutluk-İtalya ilişkileri ve Tiran Paktı hakkında mesajlarını iletme gereği duydu. Önce konuyu yeni imzalanan pakta getirdi ve Gazi, Fico'ya; “Zogu paktı imzaladı̆̆ına iyi yaptı. Sizin için kurtarıcı ve gerekliydi" sözlerini söyledi.

Gazi, paktın imzalandığını kabul ediyor, ancak Arnavutluk-İtalya ilişkilerinden kaygı duyuyordu. Çünkü İtalya, Akdeniz'de yayılmayı düşündüğü gibi Balkanlar üzerinden Türkiye'yi tehdit edebilecek potansiyele sahipti. Bu nedenle Gazi, İtalya'nın Arnavutluk üzerinden Balkanlarda nüfuz

\footnotetext{
${ }^{54} 20$ Ağustos 1928,jpg 69-2.

${ }^{55}$ Rauf Bey günlüğüne sadece balo diye not almıştır.

${ }^{56}$ Utkan Kocatürk, Kaynakçalı Atatürk Günlüğü (Doğumundan Ölümüne Kadar), Atatürk Araştırma Merkezi, Ankara 2007, s. 399.
} 


\section{ANKARA ELÇİSİ RAUF FİCO’NUN GÜNLÜKLERİ IŞIĞINDA KRALLIK İLANI ÖNCESİ TÜRKIYYE-ARNAVUTLUK İLIŞKILERINNE ATATÜRK'ÜN YAKLAŞIMI}

edinmesini, Balkanlar ve Türkiye açısından tehlikeli buluyor ve İtalya konusunda Arnavutluk'u uyarma gereği duyuyordu.

Arnavutluk Cumhurbaşkanına tavsiye ve uyarılarına; "demokrat gibi hareket etsin ve dikkatli olsun" sözleriyle başladı. Devamında uyarılarının şiddetini artırarak; "Italya karşısında özellikle içişlerinde fazla taviz vermesin (eğilmesin)" dedi. Son söylediği sözü havada bırakmayacağını gösterircesine kararlılıkla; "Italya müdahale ederse, ben de (İtalya'ya) müdahale ederim" dedi. Bu sözü öylesine içten söylemişti ki, hemen devamında; "bunun için şeref sözü veririm" dedi. Biraz düşündü ve uyarılarının dozunu yeniden düşürerek; "Ahmet'in kral" olacă̆l söylense de bravo bunu yapmadl. 20. yüzyılın gidişatını anlamış. Benden selam ilet" dedi. Aslında Arnavutluk'un Tiran Paktı'nı imzalamakla İtalya'ya yarı bağımlı hale geldiğini gören Gazi, bunun önünü alabilmek için tüm davetlilerin ve diplomatların, dolayısıyla da dünyanın önünde ve hatta tarihin önünde mesajını veriyordu. Bu balo Atatürk için adeta siyasî mesajını diplomatlar aracılığıyla dünya kamuoyuna en kısa yoldan iletme yeri haline gelmişti.

Sonra Gazi, yanına Tiran Paktı nedeniyle Arnavutluk'u eleştiren Yunus Nadi'yi ${ }^{58}$ çağırdı ve "(Pakt), Zogu'nun bir kurtulma mantı̆̆ı̆dır. Sen Sirplart nasil olduğunu bilmiyorsun" demek suretiyle Arnavutluk'un Sırbistan'a karşı İtalya desteğini aradığını belirtme gereği duydu. Yeniden Arnavutluk Elçisi Fico'ya döndü ve Mussolini ile ilgili olarak “onun rolü çabuk bitecek" dedi. Konuşmasını bitirdikten sonra tüm söylediklerinin altına imzasını atıyormuş gibi samimiyetini göstererek Arnavutluk Elçisini beklenmedik bir biçimde yanına çekip kucakladı ve öptü. Bu duruma şaşıran Arnavutluk Elçisi de beklenmedik bir şekilde Gazi’nin elini öptü. ${ }^{59} \mathrm{Bu}$

57 Türk Millî Mücadelesi devam ederken, TBMM Hükümeti ile Arnavutluk Hükümeti temsilcileri arasında İstanbul'da imzalanan on iki maddelik gizli anlaşmanın sekizinci maddesi Arnavutluk için Cumhuriyet rejimini karar altına alıyordu: "Kurulacak olan Arnavutluk Meclisinde rejim konusu belirlenecek ve halk iktidarının sağlanması için her türlü özen gösterilecek." Henüz her iki ülke işgallere karşı mücadeleye devam ederken imzalanan bu anlaşma maddesiyle Atatürk, sadece Türkiye için değil, Arnavutluk için de Cumhuriyet rejimini ön görmekteydi, Özcan "TBMM Hükümeti...", s. 127. Bu nedenle Balkanlarda Türkiye'nin dişında bir tek Arnavutluk'un Cumhuriyet rejimini sürdürmesini önemsiyor ama Cumhurbaşkanı Zogu'nun da krallık ilan edeceğini tahmin ettiği için onu ikaz ediyordu.

${ }^{58}$ Yunus Nadi, 16 Ocak 1927 günü (s. 1), “Arnavutluk Meselesi” başlığı ile yazdığı makalede; Tiran Paktı'nı daha çok Arnavutluk'un bağımsızlığı ve geleceği açısından değerlendirdi. Bu anlaşmanın Arnavutluk meclisince onaylamasına şaşırdığını ifade etti. Yunus Nadi, İtalya'nın bu anlaşma ile yeniden istilâ devrini açabileceği endişesini ayrıca vurgulamak suretiyle geleceğe ilişkin çok doğru bir tahminde bulundu, Cumhuriyet Gazetesi 16 Ocak 1927, s. 1. 5924 Şubat 1927,jpg 29-1 (EK-2). 
görüşmeden birkaç gün sonra, Polonya Elçisi Kovalski, Gazi ile görüşmüş ve görüşmede Gazi, Fico'yu ona çok övmüştü. ${ }^{60}$

Dışişleri Bakanı Tevfik Rüştü Bey, Rauf Fico ile görüşmesinde Arnavutluk Türkiye Elçisi Tahir Lütfü Bey’den gelen şifre telgrafı gösterdi. Telgrafa göre Cumhurbaşkanı Zogu, Türk Elçisi Tahir Lütfi Bey’i kabul ederek, Gazi'nin Fico'ya baloda söylediklerinden müteşekkir olduğunu ifade etmiştir. ${ }^{61}$ Aynı akşam, Ankara' da Eski Erzurum Belediye Başkanı ve Manisa Milletvekili Nafiz (Dumlu) Bey tarafindan, Erzurumluların saygı ve bağlıklarını sunmak üzere Atatürk şerefine verildiği baloya ${ }^{62}$ Rauf Bey de katıldı ve baloda Gazi, Rauf Bey'i iki kez selamladı. ${ }^{63}$

\section{Hilâl-i Ahmer'in Balosunda Gazi'nin Tavsiyesi}

Rauf Bey, Hilâl-i Ahmer'in kuruluş y1ldönümü nedeniyle 28 Nisan 1927 günü verilen baloda ${ }^{64}$ Gazi ile karşılaştı. Gazi, "Zogu'ya selam söyle" dedikten sonra Rauf Fico'ya; "iyi kumandan" tavsiyesinde bulundu ve "bunlar (iyi kumandanlar) kötü bir orduyu bile yola getirirler" dedi. ${ }^{65}$ Fico, 29 Nisan günü günlügüne yeniden bir önceki gün baloda Gazi ile karşılaşmasını tekrar düşünüp yazdı: “Arnavutluk'u sordu ve orduyu düzeltin tavsiyesinde bulundu". Yazmaya devam etti: "Iyi bir komutan en kötü orduyu bile düzeltir, yola getirir" dedi. Son cümleyi: "Yani gidin subaylarınızı düzeltin" diye yazd1. ${ }^{66}$

Gazi Mustafa Kemal Paşa, daha önceki resepsiyonda İtalya'nın saldırganlığı ve sömürgeci tutumuna karşı Arnavutluk'u tüm diplomatların ve davetlilerin önünde uyarmış ve hatta gerekirse kendisinin de İtalya saldırısına karşı destek vereceğini söylemişti. İki ay sonra, İtalyan saldırısına karşı Arnavutluk'un kendi ordusu ve savunma gücünün oluşturulmasını zorunlu gördügünü ifade etti. Sonra da Türk Millî Mücadelesinde kendi komutanlığını ve liderliğini hatırlatır gibi iyi bir komutanın ordunun durumu kötü olsa bile orduyu düzeltebileceğini yani ülkesini savunabilecek düzeye getirebileceği mesajını verdi.

${ }^{60} 1$ Mart 1927,jpg 32-1.

${ }^{61}$ Fico, konuşmanın devamı 25 Mart sayfasının başına "\% işareti” koyarak yazmış

${ }^{62}$ Kocatürk, a.g.e., s. 399.

${ }_{63} 24$ Mart 1927, jpg 43-2, jpg 44-1.

${ }^{64}$ Hakimiyet-i Milliye Gazetesi, 30 Nisan 1927, s. 1.

6528 Nisan 1927, jpg 61-2 (EK-3).

${ }^{66} 29$ Nisan 1927, jpg 62-1. 


\section{ANKARA ELÇİIİ RAUF FİCO'NUN GÜNLÜKLERİ IŞIĞINDA KRALLIK İLANI ÖNCESİ TÜRKIYYE-ARNAVUTLUK İLIŞKILERINNE ATATÜRK'ÜN YAKLAŞIMI}

\section{TBMM'de Gazi'yi Tebrik}

Arnavutluk Ankara Elçisi Rauf Fico Bey, Türkiye Cumhuriyeti'nin kuruluşunun dördüncü yılı kutlamaları için 29 Ekim günü saat 13.30'da Türkiye Büyük Millet Meclisi'ne gitti. Törene hepsi özenle giyinmiş yaklaşık 5.000 kişi katılmıştı. Önce subayların, sonra askerlerin geçişi izlendi. Sonra kulüpler, okullar, halk ve esnafin tören geçişi yaptı. Akşam resepsiyonda 1.200 'den fazla insan vardı. Gazi ile İsmet Paşa ve T. Rüştü ile görüştü. ${ }^{67}$

1927 milletvekili genel seçimleri iki dereceli olarak 2-6 Eylül tarihleri arasında yapılmıştır. 1 Kasım 1927 günü önce seçilen milletvekilleri tek tek yemin etti. Öğleden sonra saat 14:00'de Meclis tekrar açıldığında Gazi Paşa, ikinci kez Cumhurbaşkanı seçildiğinden yemin etti ve kısa bir konuşma yaptı. Gazi bakanların, katılımcıların, diplomatların ve Rauf Fico'nun tebriklerini kabul etti. ${ }^{68}$

\section{Dışişleri Bakanlığı Resepsiyonunda Gazi ile Görüşme}

Dışişleri Bakanı Tevfik Rüştü Bey ve eşinin 20 Şubat 1928 gecesi vermiş olduğu resepsiyonu Gazi Mustafa Kemal Paşa da şereflendirdi. ${ }^{69}$ Resepsiyona davetli olarak katılan Rauf Fico, ikinci kez Gazi ile görüştüğünde, Gazi, elçi'yi yanına alarak ayrı bir yere geçti. Elçi'den Arnavutluk'un durumunu sordu. Cumhurbaşkanı Zogu'ya ${ }^{70}$ "dostluğunu ve selamlarını" iletmesini söyledi. Elçiye kendi devletini iyi temsil ettiğinden dolayı teşekkür etti. Sonra "geçen yıl söylediğim sözler gerçekti" diye Mussolini ve İtalya hakkında söylediklerini hatırlatma gereği duydu. Gazi, Tevfik Rüştü Bey’i çağırdı ve Fico'nun yanında; "iki yll önce Italya ve Yugoslavya ile olan anlaşmazlığa ne tavsiyelerde bulundun?" diye sordu. T. Rüştü Bey de "Rusya, Arnavutluk'a karşı sempati besliyor" diye cevap verirken Sovyetler Birliği Elçisi Suriç geldi ve T. Rüştü Bey’i onayladı. ${ }^{71} \mathrm{Bu}$ girişim (SSCB'nin Türkiye'nin de oluruyla Arnavutluk'a desteği) ile

\footnotetext{
${ }^{67} 29$ Ekim 1927, jpg 141-2.

${ }^{68} 1$ Kasim1927,jpg, 143-2.

${ }^{69}$ Kocatürk, a.g.e., s. 409.

70 Mati kabilesinin şefi Cemal Paşa'nın ikinci oğlu olan Ahmet Zogu, 8 Ekim 1895'te çevresinde 150 hanelik küçük bir köy bulunan Burgayet kalesinde doğmuştur. Manastır'daki Askerî Lise'de bir süre öğrenim gördükten sonra İstanbul Galatasaray Lisesi’nde eğitimini tamamlamıştır. Türkçeyi çok iyi konuşur, şiir ve edebiyata düşkündür ve Hakkı Tarık Us'un "Vakit" Gazetesinde bir süre muhabirlik yapmıştır. 1925 yılında Başbakan ve Cumhurbaşkanı, 1928 yılında da Kral olmuştur, Özcan, a.g.e., s. 144.

7120 Şubat 1928,jpg 162-2.
} 


\section{HALİL ÖZCAN}

İtalya'nın Arnavutluk üzerindeki etkisini önce azaltmak sonra ortadan kaldırılmak isteğinin bir yansıması olarak da değerlendirilebilir.

\section{Sonuc}

Rauf Fico, Arnavutluk Cumhuriyeti'nin Türkiye Cumhuriyeti nezdindeki ilk elçisi ve eski bir Osmanlı bürokratıdır. Türkiye-Arnavutluk siyasî ilişkilerinin başlaması döneminde Ankara'da görev yapmıştır. Onun görev yaptığı dönem, Türkiye ve Arnavutluk'un yeni rejimlerini oluşturmaya ve dolayısıyla da dış politikalarını şekillendirmeye başladıkları yıllara denk gelmesi açısından önemlidir.

Türkiye, bu dönemde tam bağımsızlığını savaş ile kazanan ve egemenlik haklarını kendi iradesiyle kullanan bir devlettir. Cumhuriyetin temellerini atarken, on yıl aralıksız süren savaşın yaralarını sarmaya ve mübadele göçmenlerini iskân etmeye öncelik vermiştir. Dolayısıyla kaynaklarını içeride kullanabilmek için dış politikada çatışma ve savaş söylemlerinden uzak durmaya gayret etmekle birlikte Lozan'dan kalan ve sonradan çıkan kimi sorunlarını da diyalog ve uluslararası hukuk temelinde çözmeye çalışmıştır.

Arnavutluk ise, kendi kaynaklarını verimli kullanamadığı için iktisadî açıdan dış yardım imkânlarını aramış, Kosova başta olmak üzere diğer Balkan ülkelerindeki Arnavutların sorunlarını büyük bir devletin yani İtalya'nın yardımıyla kendi lehine çözmeye çalışmıştır. İtalya, Akdeniz'de kendisine I. Dünya Savaşı'nda vaat edilen yerleri yeniden talep etmekte, 12 Ada ile yetinmek istememekte ve Balkanlarda nüfuz edinmeye gayret göstermiştir. Ayrıca İtalya, Bulgaristan ve Arnavutluk ile kurduğu yakın ilişkilerle, Türkiye'yi Trakya ve Boğazlardan tehdit eder duruma gelmektedir.

Atatürk, Arnavutluk'un Yugoslavya tehdidi nedeniyle İtalya'ya yaklaşmasını denge olarak değerlendirmiştir. Ancak İtalya'nın gerçek niyetini tahmin ettiği için Arnavutluk Elçisini uyarma gereği duymuştur. Atatürk'ün uyarısını dikkate almayan Arnavutluk Cumhurbaşkanı Ahmet Zogu da gittikçe İtalya'ya yaklaşmış ve Türkiye'den uzaklaşan bir politika takip etmiştir. Arnavutluk bağımsızlığını elde etmesine rağmen İtalya ile kurmuş olduğu ilişki, onu yeni bir bağımlılığa sürüklemiştir. 1 Eylül 1928'de İtalya'nın desteği ile Krallığını ilan eden Ahmed Zogu karşısında Gazi Mustafa Kemal Paşa bu ilişkinin Arnavutluk'un bağımlılığını 
ANKARA ELÇİII RAUF FICO'NUN GÜNLÜKLERİ IŞIĞINDA KRALLIK İLANI ÖNCESI TÜRKIYYE-ARNAVUTLUK İLIŞKILERINNE ATATÜRK'ÜN YAKLAŞIMI

derinleştireceğini görüp, Kral Zogu'nun bu kararına tepki olarak Tiran'daki Türk Elçisini Ankara'ya çağırmıştır. Arnavutluk'ta dış politikadaki eksen kayması, 1 Eylül 1928 'de Krallığın ilanıyla başlayan süreç olmuştur. Fico'nun günlükleri o dönem hakkında bilgiler verdiği ve Arnavutluk bakış açısını yansıtığı için ayrıca kıymetlidir. 
HALIL ÖZCAN

\section{EKLER}

\section{EK-1}

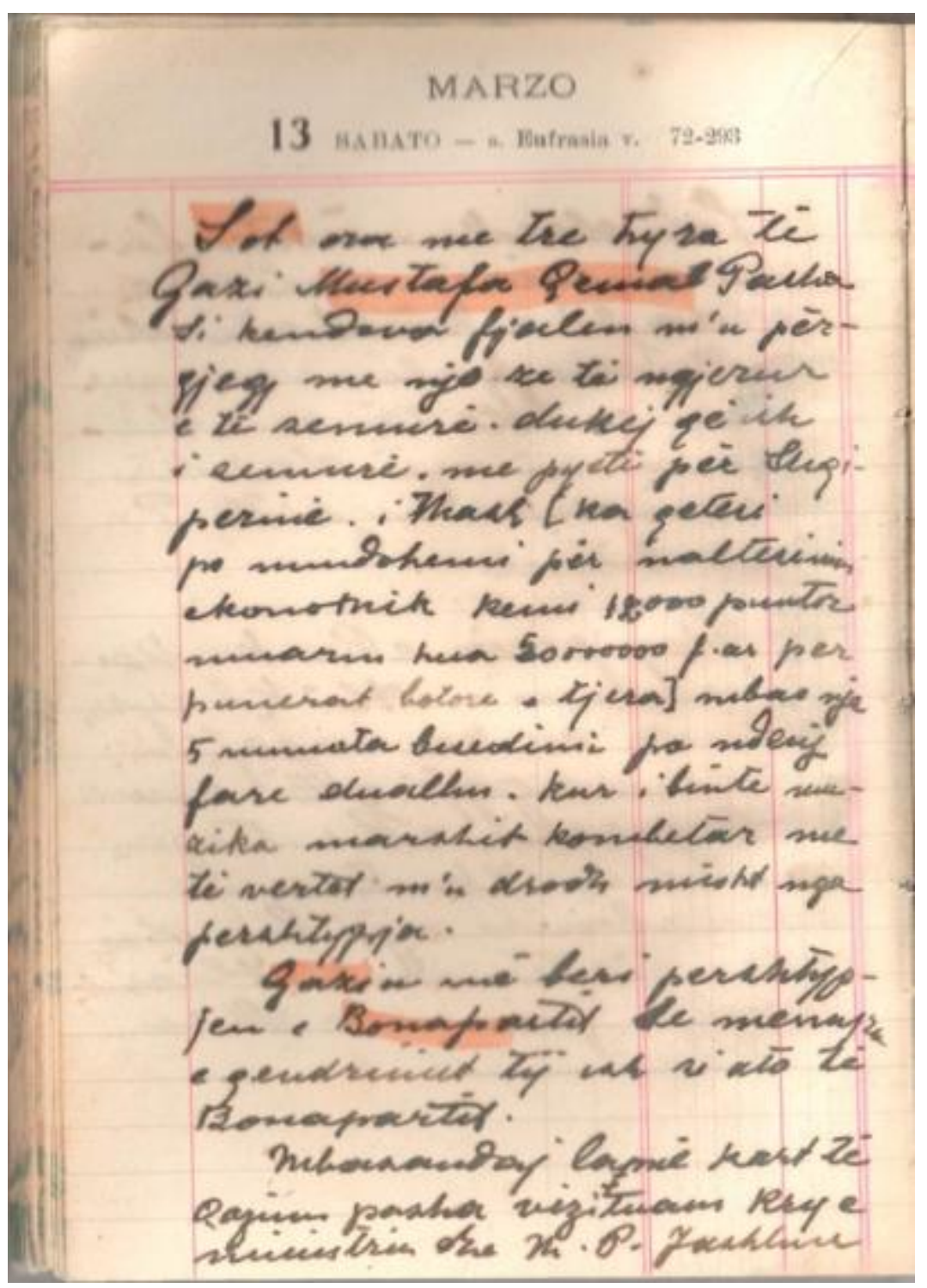

13 Mart 1926, jpg 38-1: Rauf Fico'nun güven mektubunu sunmas1. 
ANKARA ELÇİII RAUF FICO'NUN GÜNLÜKLERI IŞIĞINDA KRALLIK İLANI ÖNCESİ TÜRKIYYE-ARNAVUTLUK İLIŞKILERINNE ATATÜRK'ÜN YAKLAŞIMI

EK-2

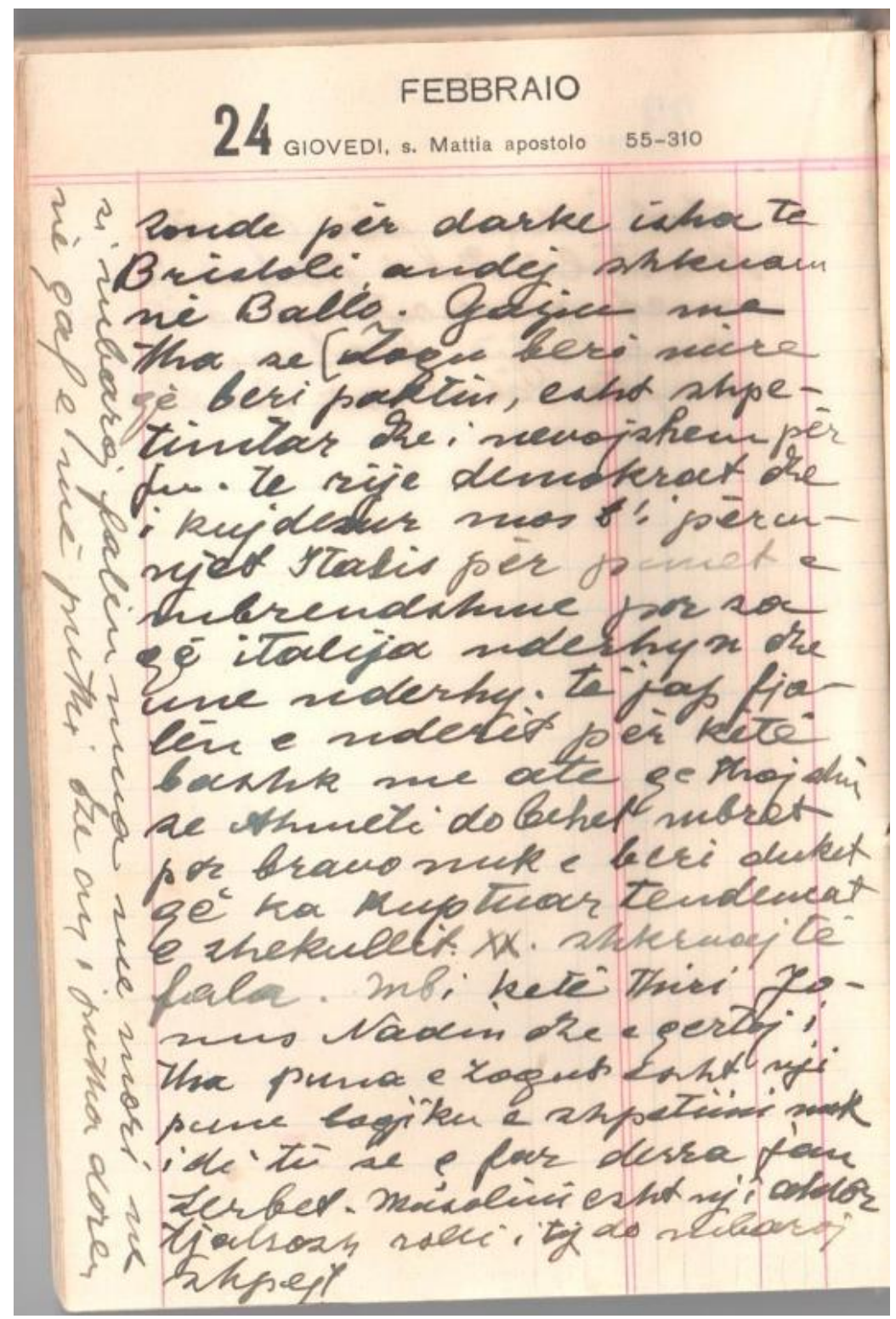

24 Şubat 1927, jpg 29-1: Gazi'nin Arnavutluk Elçisi Fico’ya Tiran Paktı ve İtalya hakkındaki konuşması. 


\section{HALİL ÖZCAN}

\section{EK-3}

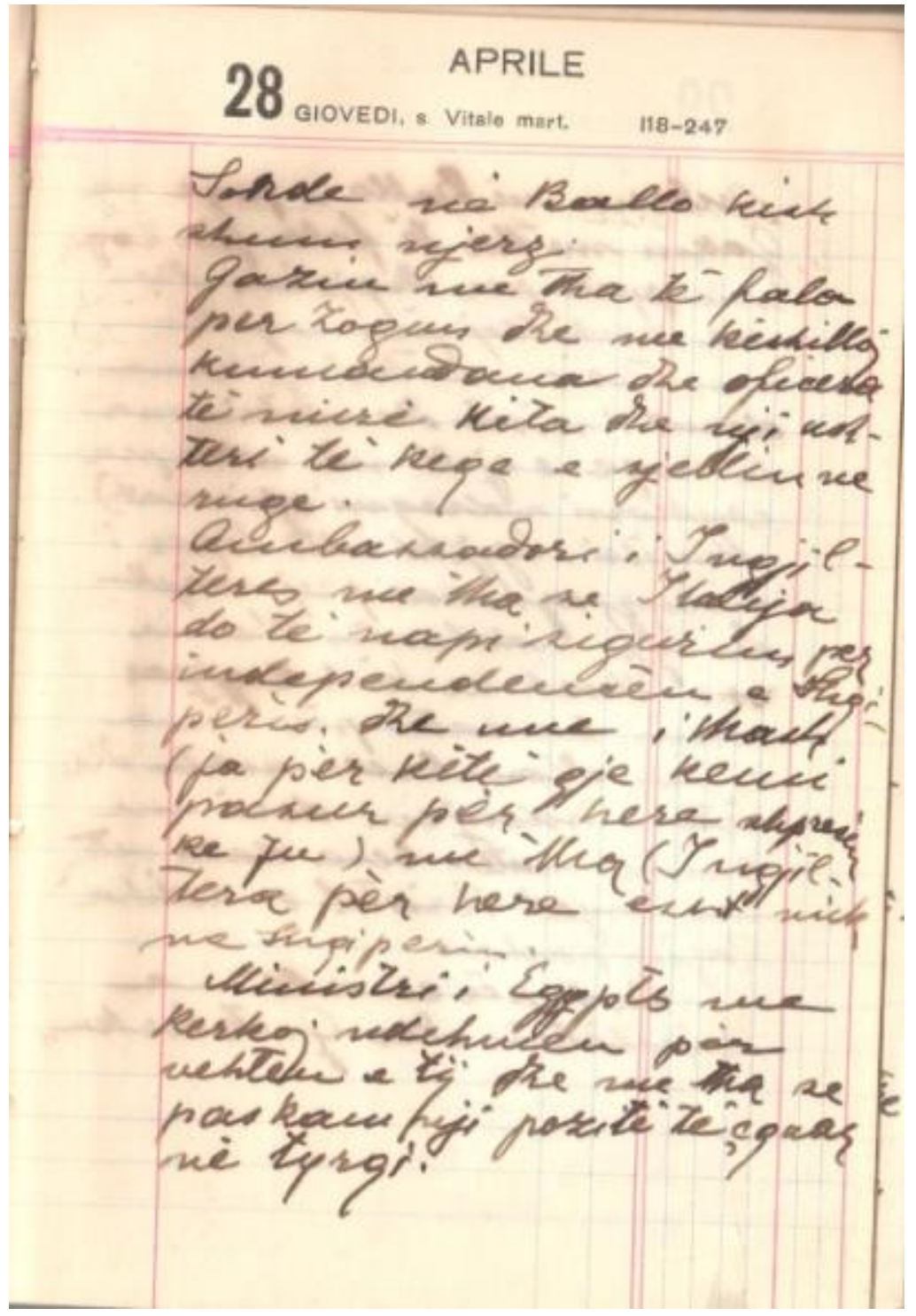

28 Nisan 1927, jpg 61-2: Hilâl-i Ahmer Balosunda Gazi’nin Rauf Fico’ya iyi kumandan tavsiyesi. 
ANKARA ELÇİSi RAUF FİCO'NUN GÜNLÜKLERİ IŞIĞINDA KRALLIK İLANI ÖNCESİ
TÜRKIYYE-ARNAVUTLUK İLIŞSİLERINE ATATÜRK'ÜN YAKLAŞIMI

\section{KAYNAKÇA}

\section{Rauf Fico’nun Günlükleri}

11 Nisan 1925, 16 Nisan 1925, 8 Nisan 1925, 20 Nisan 1925, 23 May1s 1925, 24 Haziran 1925, 28 Temmuz 1925, 4 Ocak 1926, 5 Ocak 1926, 13 Ocak 1926, 15 Ocak 1926, 16 Ocak 1926, 7 Şubat 1926, 9 Şubat 1926, 12 Şubat 1926, 13 Şubat 1926, 14 Şubat 1926, 13 Mart 1926, 19 Nisan 1926, 19 Nisan 1926, 20 Nisan 1926, 20 Ağustos 1928, 15 Şubat 1926, 22 Şubat 1921, 23 Şubat 1926, 7 Mart 1926, 9 Mart 1926, 10 Mart 1926, 13 Mart 1926, 24 Şubat 1927, 1 Mart 1927, 24 Mart 1927, 28 Nisan 1927, 29 Nisan 1927, 29 Ekim 1927, 1 Kasım1927, 20 Şubat 1928.

\section{Gazeteler}

Cumhuriyet, 4 May1s 1925.

Tanin, 28 Mart 1925.

Hâkimiyet-i Milliye, 30 Nisan 1927.

\section{Kitap ve Makaleler}

Atatürk'ün Bütün Eserleri (1925-1927), Cilt: 18, Kaynak Yayınları, İstanbul 2006.

SHQYRI, Hys1, Rauf Fico Shtetar Dhe Diplomat I Shquar (Monografi), Tiranë 2007.

KILIÇ, Sezen, "Musul Sorunu ve Lozan”, http://www.atam.gov.tr/dergi/sayi71/musul-sorunu-ve-lozan, (18.08.2018).

KISIKLI, Emine, "Yeni Gelişmelerin Işığında Geçmişten Günümüze Musul Meselesi," Ankara Üniversitesi Türk İnklâp Tarihi Enstitüsü Atatürk Yolu Dergisi, S. 24, Kasim 1999-2003, ss. 487-526.

KOCATÜRK, Utkan, Kaynakçalı Atatürk Günlüğü (Doğumundan Ölümüne Kadar), Atatürk Araştırma Merkezi, Ankara 2007.

ÖZCAN, Halil, Atatürk Dönemi Türkiye-Arnavutluk Illişkileri (1920-1938), Atatürk Araştırma Merkezi, Ankara 2011. 


\section{HALİL ÖZCAN}

, “Lozan Konferansı Tutanakları ve Arnavutluk'un Atina Büyükelçiliği Raporları Temelinde Mübadelede Yunanistan'daki Müslüman Arnavutların Durumu", Hacettepe Üniversitesi Atatürk Illkeleri ve İnklâp Tarihi Enstitüsü Cumhuriyet Tarihi Araştırmaları Dergisi (CTAD), Ankara, Y1l: 13, Say1: 25, Bahar 2017, ss. 50-79.

,"TBMM Hükûmeti ile Arnavutluk Hükûmeti Arasında İmzalanan Gizli Anlaşmanın Sebep ve Sonuçları”, İstanbul Gelişim Üniversitesi Sosyal Bilimler Dergisi, Cilt: 4, Say1: 2, Ekim 2017, ss. 119-157.

ÖZLER, A. Baha, "Yakın Tarihimizin Gizli Kalmış Tarafları: Atatürk'ün Arnavutluk Hakkında Siyasî Bir Kehaneti”, Tarih Dünyası Dergisi, Sayı: 35, 26 Kasim 1952, ss. 1411-1414.

SOYAK, Hasan Rıza, Atatürk'ten Hatıralar, Yapı Kredi Yayınları, 3. Bask1, İstanbul 2006.

ŞİMŞİR, Bilâl N., Atatürk ve Yabancı Devlet Başkanları, C. I, Türk Tarih Kurumu, Ankara 1993.

TOSUN, Hüseyin, "Montrö Boğazlar Sözleşmesi (Boğazlar Sorununda Son Aşama)", Ankara Üniversitesi Türk İnklâp Tarihi Enstitüsü Atatürk Yolu Dergisi, Say1: 13, 1994, ss. 88-112.

TÜRKEŞ, Mustafa, “Atatürk Döneminde Türkiye'nin Dış Politikaları (19231938)", Ankara Üniversitesi Siyasal Bilgiler Fakültesi, Uluslararası Atatürk ve Modern Türkiye Konferansl, 22-23 Ekim 1998, Ankara, ss. 129-142.

, "The Balkan Pact and Its Immediate Implications for the Balkan States, 1930-1934”, Middle Eastern Studies, 30/1, 1994, pp. 123-144.

YEL, Selma, Değişen Dünya Şartlarında Karadeniz ve Boğazlar Meselesi (1923-2008), Atatürk Araştırma Merkezi, Ankara 2009.

Yunus Nadi, “Arnavutluk Meselesi”, Cumhuriyet Gazetesi, 16 Ocak 1927. 